\title{
13 \\ Protecting Our Shadow: Repatriating Ancestral Recordings to the Lihir Islands, Papua New Guinea
}

\author{
Kirsty Gillespie
}

\section{Introduction}

I first visited the Lihir Island Group in New Ireland Province, Papua New Guinea, in September 2007. As I prepared that year for my last trip to the Highlands region for my doctoral research, I felt the need to experience more of the many diverse cultures that make up the country. I determined to travel to the coast, which was to me the antithesis of the Highlands, after completing my doctoral fieldwork. As luck would have it, some of my extended family had just moved to the Lihir Islands in July of that year; the opportunity to spend some time at the other end of the country, amongst island culture, suddenly presented itself.

I mentioned my plans to colleagues at The Australian National University prior to my departure and discovered that, by another stroke of good fortune, fellow colleague Chris Ballard also planned to be in the Lihir Islands at the same time, conducting a social impact assessment in the company of anthropologist Nick Bainton. In his office Chris gave me a quick overview of Lihir, sketching for me a map of the islands 
on a yellow post-it note. This conversation and quick sketch was the foundation for that first informal visit and came with an invitation to tag along with Chris while he toured the island group-an invitation I enthusiastically accepted.

It was not until several days into Chris's work and my time in the Lihir Islands that a role for me became clear. Sitting on a log with Chris on the island of Aniolam, ${ }^{1}$ looking over historical documents (applying a rudimentary knowledge of German acquired during a year spent in Germany seven years prior) I read that German museum anthropologist Otto Schlaginhaufen had made wax cylinder recordings of Lihir songs almost 100 years before. There and then I decided to seek out these recordings and bring them back to Lihir, and the chapter of my career working in the Lihir Islands began.

This chapter traces the journey of this repatriation project, both in text and image. Taking its title from a translation of the lyrics of a Lihir song that emerged as part of that project, this chapter explores the concept of the shadow from two specific standpoints. First, in its content the chapter explores the shadow of the ancestors through the traditions that they leave, in this case left through recorded form as well as oral tradition. Second, through its process the chapter addresses the shadow of researchers through the legacy that they leave (see also Barz and Cooley 1997). In both cases, the important role of archives and the ethnomusicologist's engagement with them looms large, a connection that we see embodied in the career of Stephen Wild, who spent many years employed as an ethnomusicologist with the Australian Institute for Aboriginal and Torres Strait Islander Studies (see Wild 2001). Finally, the images that illustrate the story of this repatriation project, while relating directly to the text, can be taken on their own as a photographic essay; a subtext exploring the shadow (and light) that photography plays in ethnographic research.

1 Aniolam is also known as Niolam and translates as 'the big place'/'the big island'. It is the largest island in the Lihir Island Group. 


\section{Schlaginhaufen's collection and the shadow of the researcher}

In 1907, Otto Schlaginhaufen left Germany with the Deutsche MarineExpedition (Germany Navy Expedition), one of their destinations being the islands of the Bismarck Archipelago, off the northeast coast of the mainland of Papua New Guinea. By 1908 they had reached Leo, Lihir, a quiet little bay in the south of Aniolam, the southernmost island in the group (Figure 1). ${ }^{2}$

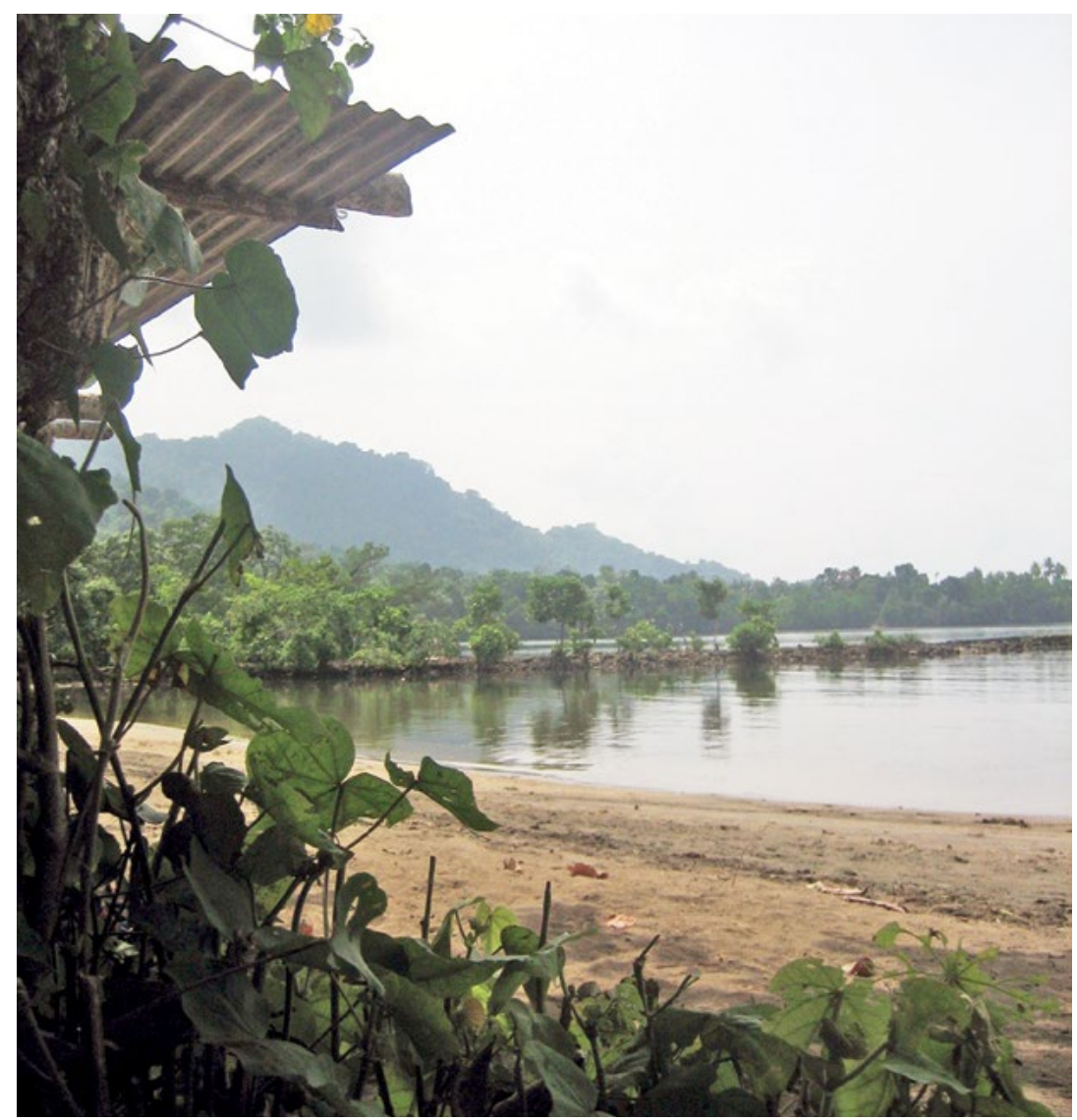

Figure 1. The shore of Leo (Aniolam, Lihir), the area where Schlaginhaufen arrived in 1908

2 See Bainton et al. (2012: 25) for a map of Aniolam drawn by Schaginhaufen, which details Leo and other locations on the island. 
It was Schlaginhaufen's evocative account of recording songs upon his arrival that caught the attention of me and Chris while we sat together on Lihir back in 2007: the watershed moment.

More than a hundred people had gathered in Leo for the aforementioned festivity of the natives; it was said, as I heard, that my phonograph had in part enticed them, as they had already heard of its miraculous ability to reproduce things spoken and sung. To begin with, one of the many people allowed themselves to be persuaded to sing a song into the phonograph's funnel. Hereupon the people listened with astonishment to the playback of what had been sung, and now the ice was broken; one after another stepped up to the phonograph and supplied a musical contribution, so that eventually I used up the entire stock of phonographic cylinders which I had brought with me to Lir. (Schlaginhaufen 1959: 133, trans. Hilary Howes)

Schlaginhaufen recorded 19 Lihir songs on 19 wax cylinders; these, if they still existed, would constitute the oldest known recordings of Lihir music. The question then was how to find them.

The Berlin Phonogramm-Archiv is known to ethnomusicologists as having the premiere wax cylinder collection in Germany with a significant number of items from Papua New Guinea (see Berlin and Simon 2002) and so was a logical place to look. Don Niles, senior ethnomusicologist at the Institute of Papua New Guinea Studies, had spent time at the Phonogramm-Archiv as a visiting researcher in 1993 and confirmed that they did indeed hold these recordings of Schlaginhaufen's. This was further verified by the (timely) publication on the wax cylinder collections of the Phonogramm-Archiv by resident archivist Susanne Ziegler (2006). While the volume has detailed information about Schlaginhaufen's recordings in the accompanying CD-ROM, none of his recordings are reproduced there. I requested a copy of the 19 cylinder recordings, which fortuitously had already been digitised by the staff of the Phonogramm-Archiv, and I eventually received these under the condition that the recordings be used for research purposes only. Finally I had a copy of the music in my hand.

What struck me when I first heard Schlaginhaufen's 1908 recordings was the clarity of the sound. For one accustomed to listening to scratchy, barely audible historical recordings, these songs came through strong and clear. One could even hear almost perfectly the voice of Schlaginhaufen as he introduced each singer and their song. The second thing that struck me was the level of detail of the documentation that accompanied the songs. 
Schlaginhaufen had listed against the cylinder number the location of the recording; the place of origin of the singer; the singer's name, gender, and age; the genre of song; and notes on accompanying gestures, use of objects while performing (such as spears), as well as any other relevant details (see Figure 2; this information is also very helpfully typed up and reproduced in Ziegler 2006). In the absence of any known photographs from Schlaginhaufen's time in the Lihir Islands, these details paint an evocative picture. Sometimes, though, they raise more questions.

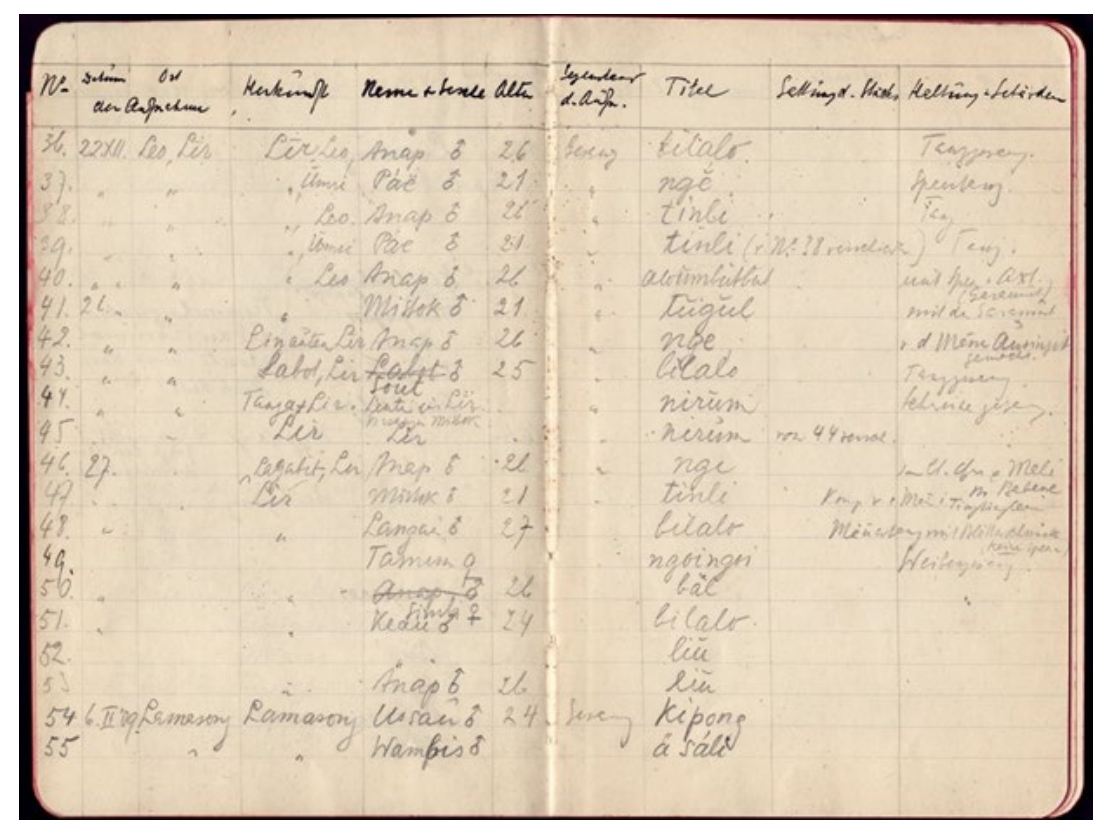

Figure 2. Schaginhaufen's notes on the Lihir recordings

Source: Berlin Phonogramm-Archiv

Take, for example, cylinder 42. From these notes we know that the song is an example of the nge song form, sung by the man Anap. The notes tell us that Anap was 26 years old when the recording was made, and under the column headed 'Haltung, Gebärden' (= Posture, Gestures) are the words 'von dem Manne Auringit gemacht' (= made by the man Auringit). It is unclear from these notes whether Auringit composed the song Anap sang, or whether he was making gestures or dancing along with Anap's performance. Still, it is very helpful information for tracing the song's history. We will return to this song in more detail shortly. 
After my initial visit to the Lihir Islands in 2007, the fledgling Lihir Cultural Heritage Committee invited me back to make further recordings of their music, with a view to producing a CD. Since it was exactly a century since Schlaginhaufen's recordings were made, it was decided that these historical recordings should ideally be included in the CD. Funds for this project were provided by Lihir Gold Limited, the company then operating the very large gold mine on the island of Aniolam. ${ }^{3}$ Mining has been in operation there since the mid-1990s and is expected to continue for decades to come. It is in this context that the cultural heritage work takes place (for more information about the connection between ethnomusicology, cultural heritage, and mining in the Lihir Islands, see Gillespie 2013).

\section{Repatriation: Listening to the shadow of the ancestors}

With a vision of a cultural resource centre that the recordings could be a part of, the Committee formally requested that a copy of Schlaginhaufen's recordings be repatriated - the Phonogramm-Archiv did not allow me to simply share with Lihir people my copy; a separate but similar process needed to take place for the Lihir people to receive their copy. There was no discussion or expectation from Lihir people around receiving the originals; it was understood that it would be impossible for the cylinders themselves to be returned (as suitable facilities for storing them do not exist) and, at any rate, the cylinders would be near useless without being playable. So a digital copy, the same as that sent to Australia for research purposes, was eventually delivered from Berlin to Lihir, coinciding with my second trip to the islands and first official visit to document Lihir music.

The first task of this CD project was to transcribe and translate the song texts of Schlaginhaufen's recordings. Peter Toelinkanut, an active member of the Committee, listened to the playback of each recording, commenting on their clarity and on the stories the songs told (Figure 3). As we wrote down these texts and translated them, it became apparent to me that Lihir songs, despite the brevity of their texts, reveal important information about Lihir culture.

3 Lihir Gold Limited is now owned and operated by Newcrest Mining Ltd, a multinational company with its headquarters in Melbourne, Australia. 


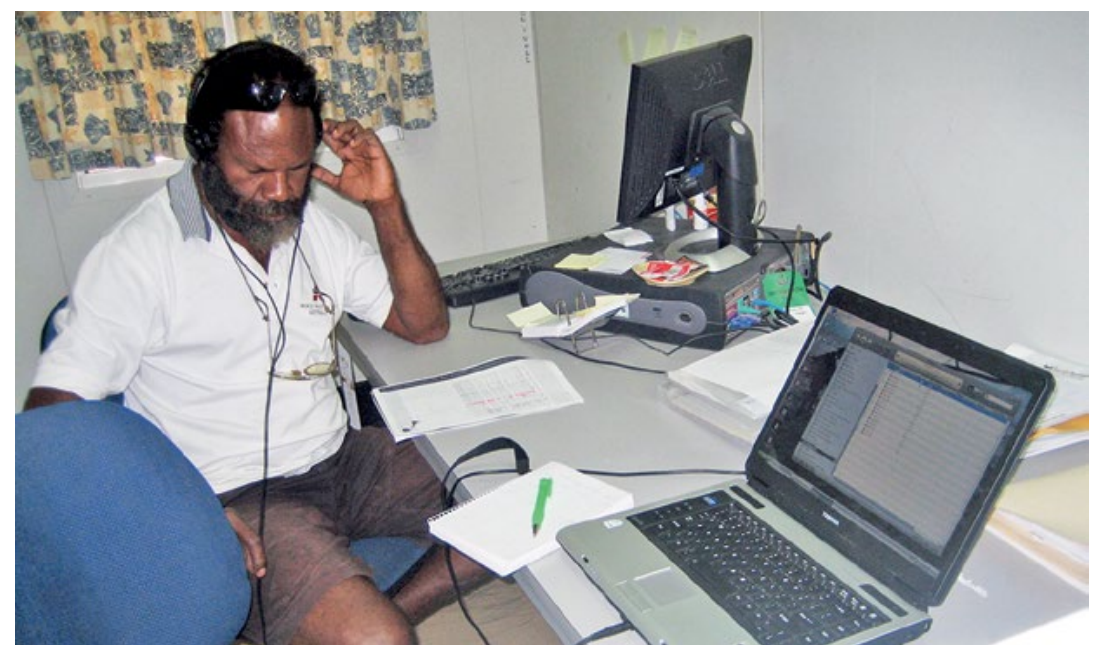

Figure 3. Peter Toelinkanut of the Lihir Cultural Heritage Committee listens to the archival recordings in the Lihir Gold Ltd's community relations office, 2008

Returning to cylinder 42 as an example, Schlaginhaufen's verbal introduction to this song follows a standard template heard on the other cylinders: 'Gesang nge aus Lir. Gesungen von dem Manne Anap, aus Leo, Lir' (= Nge song from Lihir. Sung by the man Anap, from Leo, Lir). The short text (comprising two distinct melodic/text lines) is then sung over and over, just as it would be in performance. However, rather than being repeated until the ritual dance movements come to an end, these performances are much more truncated, stopping when the cylinder runs to its end (usually just over the one minute mark).

wa nunglik do masor na ie

la bukbuk wan de ro lio

wan de bang risetan wan

de bang riselie

ra da long mai tes ${ }^{4}$ you my nephew where will we come ashore?

in the whirlpool you will draw me out

you will pour you will pour out

my blood in the saltwater

(featured on Gillespie 2008: Track 1; www.lihir.info/music-of-lihir/index. php/the-songs/songs-nge)

4 It should be noted that there is no standard orthography for the Lihir language, which is made up of a number of different dialects, thus the representation of the language here may differ from other Lihir language resources. Particularly, variation in the demarcation of syllables often occurs, as efforts are made to improve the rendering of the language. 
Like many of the cylinder recordings, this song focuses on death at sea. Lihir songs are often conceived in dreams to explain the fate of a missing or deceased person and, almost inevitably, these deaths occur at seafrom bad weather, circumstance, or at the hand of an enemy. The nge song above is likely to have been conceived in a dream by the uncle of the deceased. In the lyrics, the singer first addresses his nephew, asking where his body is to be found, to which the deceased nephew replies that he will be found in the whirlpool, with the final two lines emphasising his death. This uncle/nephew relationship is significant: Lihir is a matrilineal society, and as such, the relationship between men and their sister's sons is of primary importance to the lineage. This song then, in its few short lines, tells us a great deal about Lihirian society (this song also features in Gillespie 2016: 13). It was because of this (as well as its superior sound quality) that this song was chosen to open the CD that came to be known as Ae tinil wen Lir: Music of Lihir (Gillespie 2008).

\section{New songs from old: Protecting the ancestors' shadow}

To record current Lihir songs for the proposed CD, members of the committee and I travelled around each of the 15 wards in the island group and, as a starting point, played back the 1908 recordings to Lihir people for their comment (see Figures 4-5). We also took a copy of Schlaginhaufen's documentation, which we shared (see Figures 6-8), and headphones for those who were hard of hearing. Lihir cultural etiquette meant that I could provide headphones, but not place them on anyone's head, especially a man of high status, as reference to the head is generally to be avoided (see Hemer 2013: 36, 39, 92-93; the headphones on the head of Solgas in Figure 9 were put in place by one of his relatives). 
13. PROTECTING OUR SHADOW

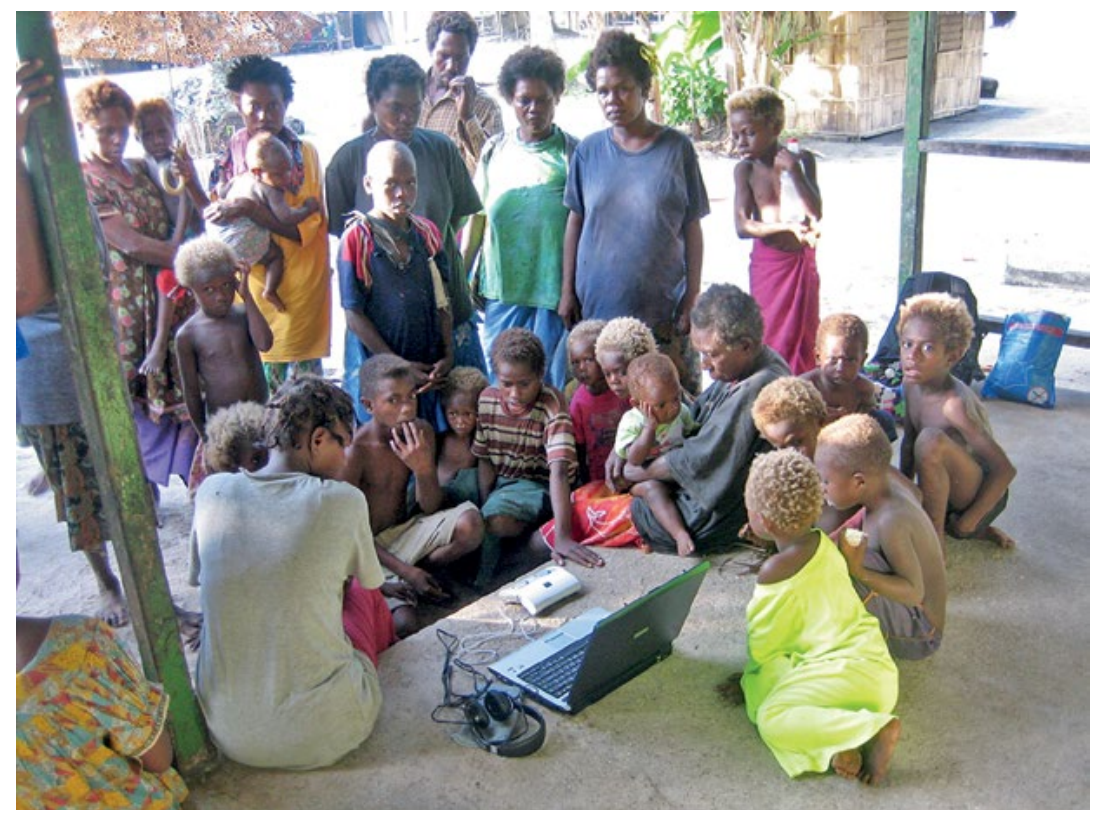

Figure 4. Women and children gather to listen to Schlaginhaufen's recordings

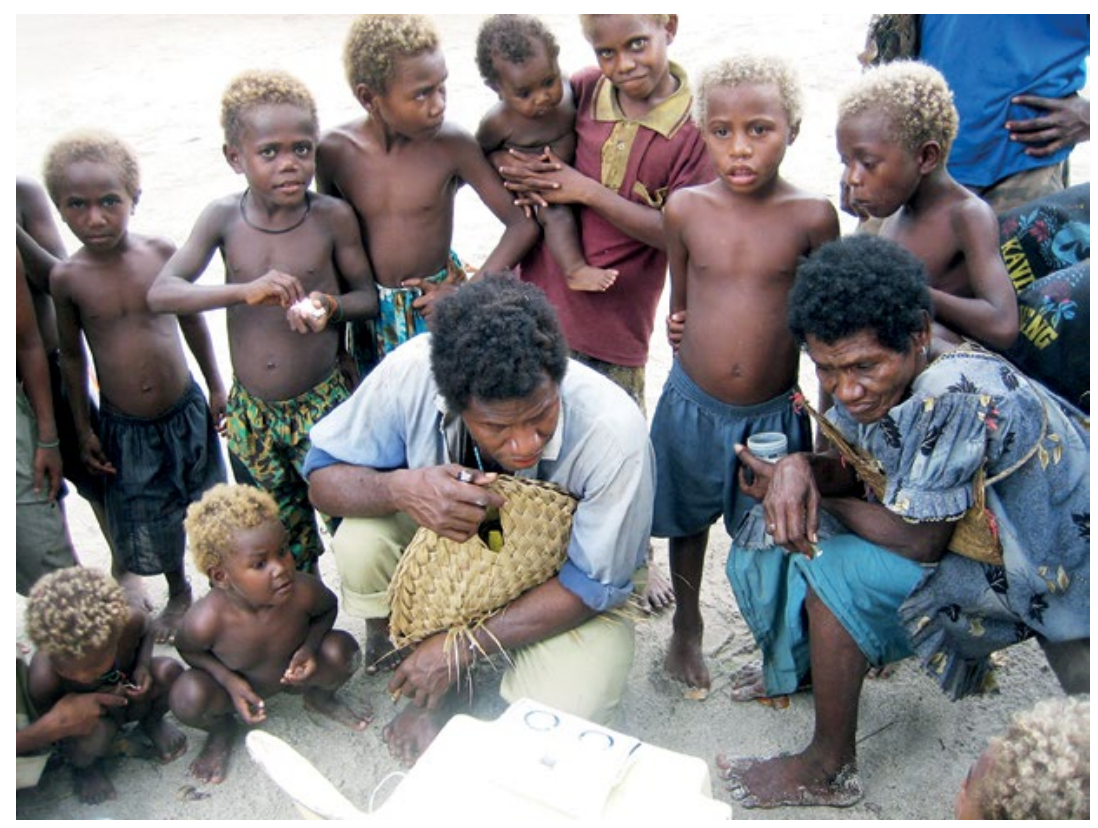

Figure 5. Listening intently to Schlaginhaufen's recordings 
A DISTINCTIVE VOICE IN THE ANTIPODES

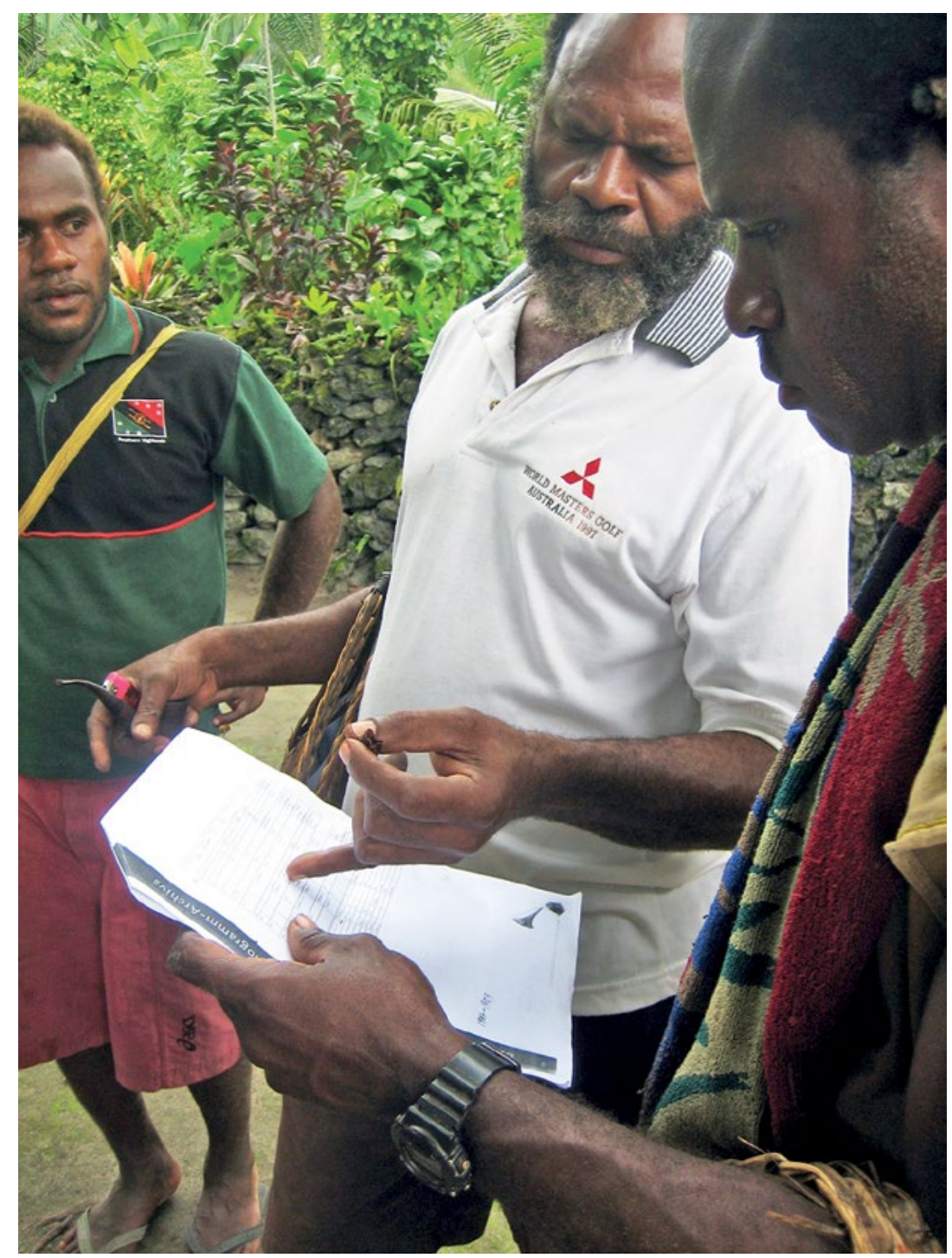

Figure 6. Peter Toelinkanut pointing out information on the Schlaginhaufen recordings from a photocopy of pages from Ziegler (2006) 
13. PROTECTING OUR SHADOW

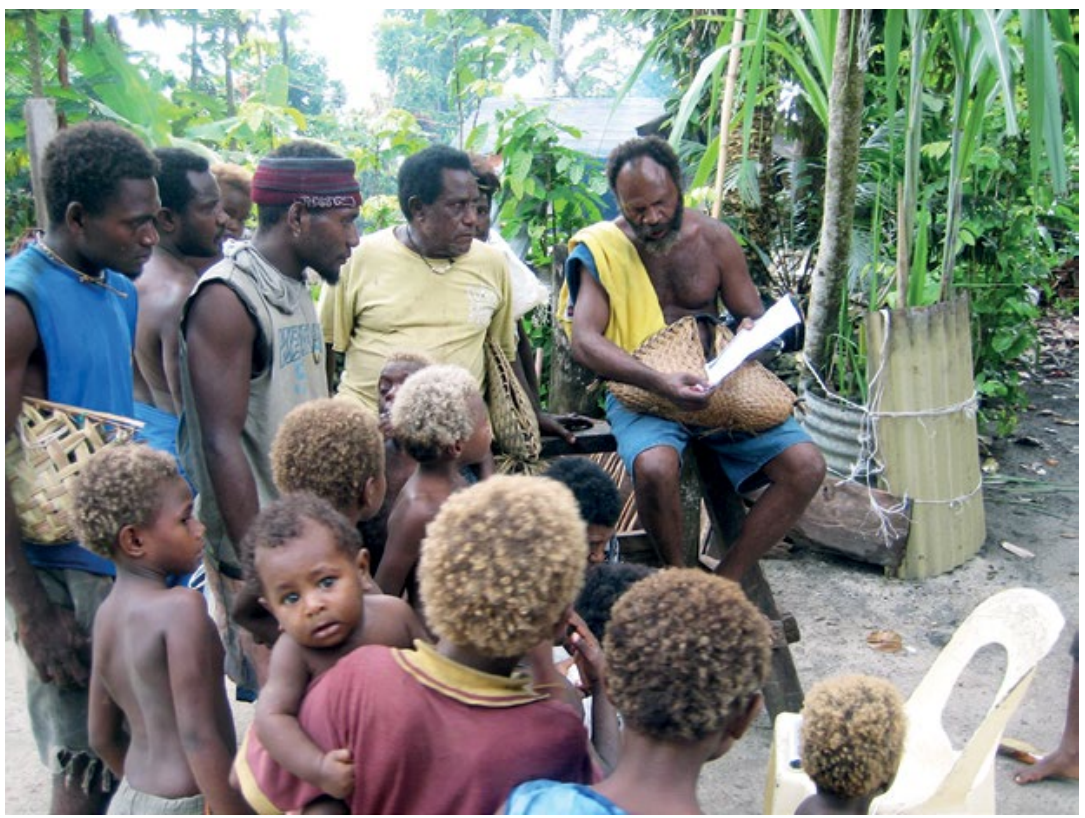

Figure 7. Peter Toelinkanut sharing information with a group of interested people from Masahet Island, Lihir Island Group

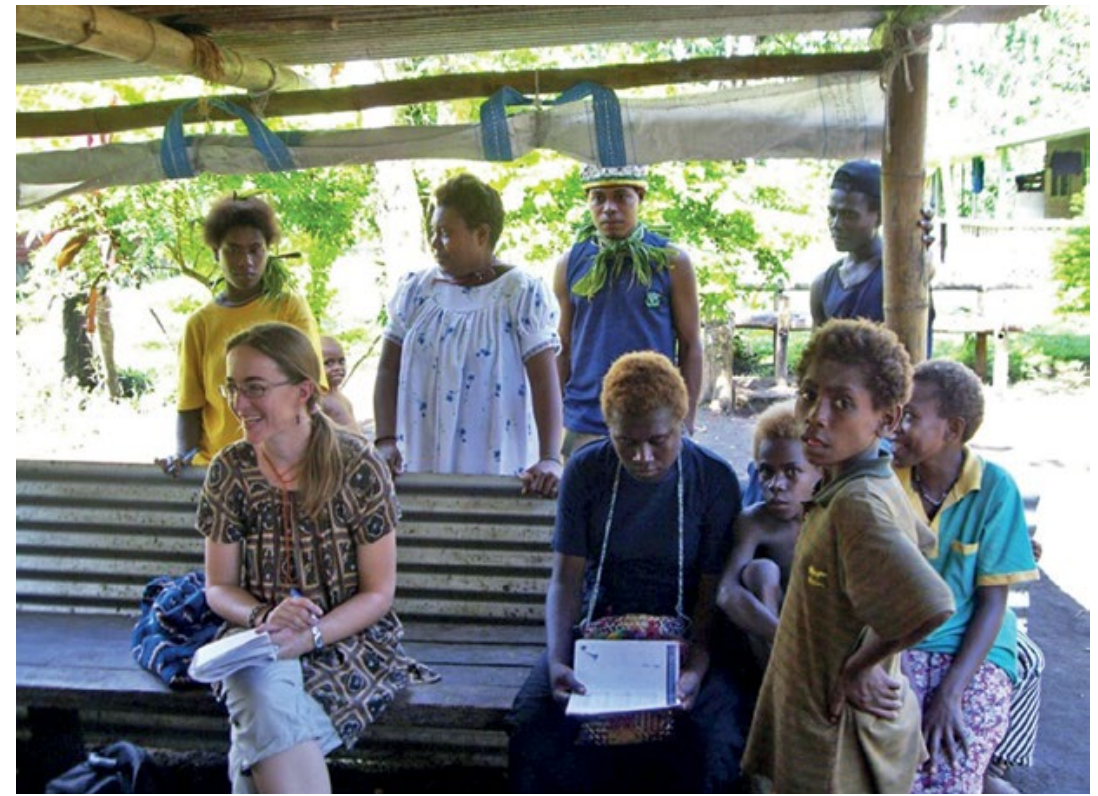

Figure 8. Young people engaging with the documentation while the author collects comments 
Many Lihir people responded to Schlaginhaufen's recordings using the genres' accompanying dance movements, even if this dancing was limited to upper body movements whilst seated (see Figures 9 and 10). This served to emphasise the integral relationship between song and dance in Lihir performance; there are few song forms that are not accompanied by movement, and the different movements become part of the defining elements of different song genres.

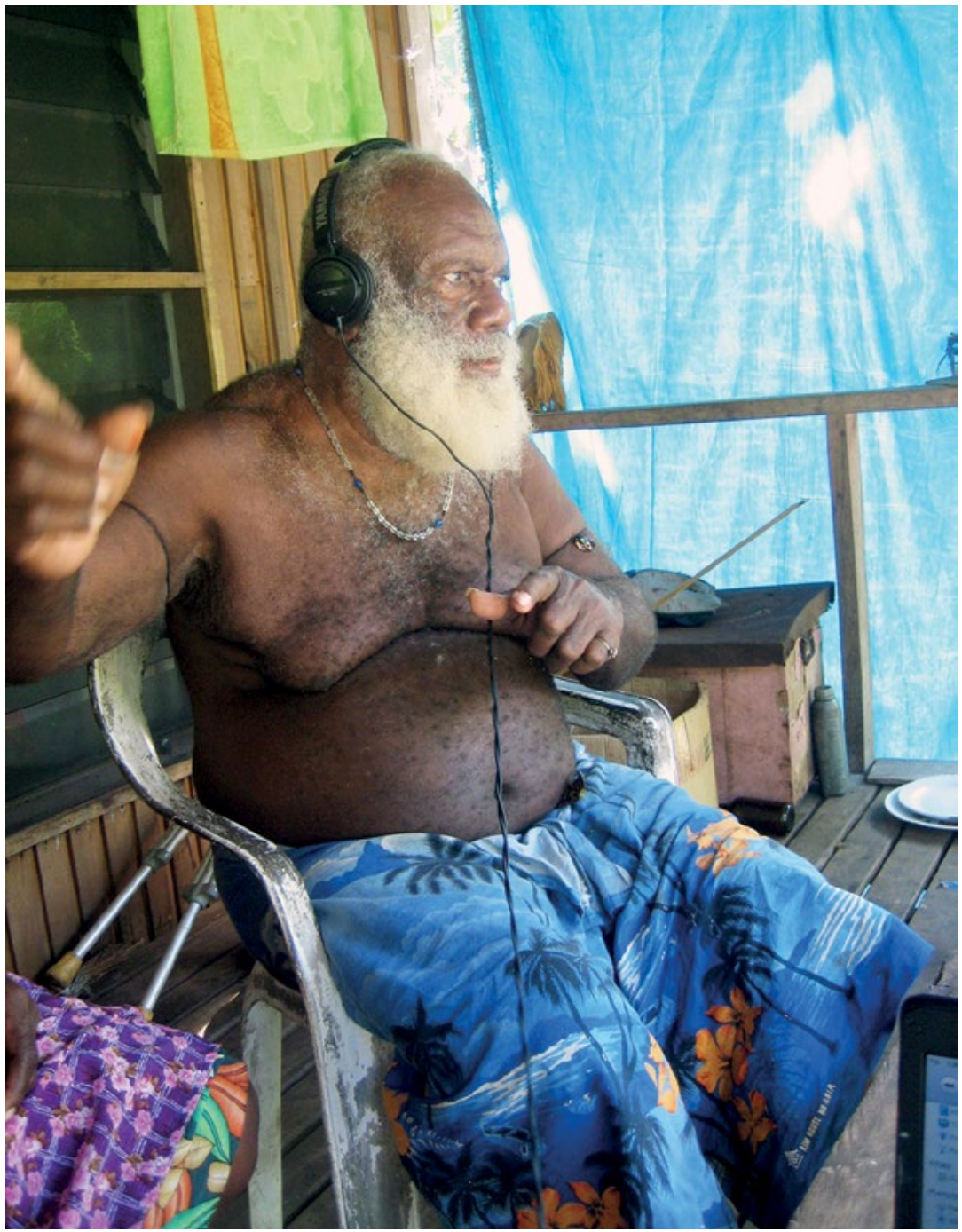

Figure 9. Michael Solgas listens to the archival recordings and dances along, seated 


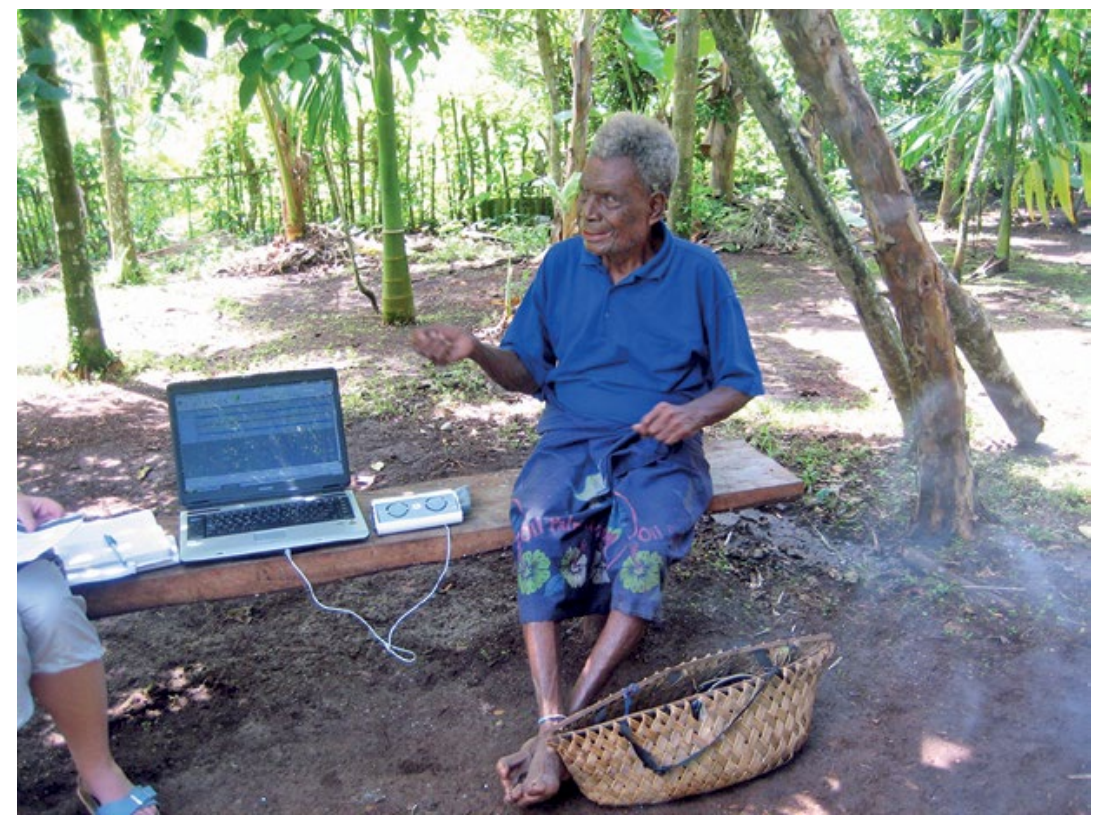

Figure 10. Alois Kokon responds to Schlaginhaufen's recordings

The 1908 recordings inspired those listening to then sing other Lihir songs for recording. While people often sang along to the playback of the earlier recordings (something facilitated by the songs' repetitive nature), most of the songs sung for recording in 2008 were different to the earlier ones (though of the same genres). Some songs stood alone as individual songs, but others were presented as part of a song 'set' or series of related songs. The example from which this chapter draws its title is an example of one such song from a set of nge songs. In this song, which was sung for recording by the Agnes Toti, the person is again at sea and the strong winds, the taste of blood, and the arrival of the tandal (spirit) within the ginger (an important plant in Lihir culture) signifies that death is on its way: ${ }^{5}$

le dora wues manung yie

lilien ma ngui lawir no ko kets pilik tan a ton don wen ngui to you and I have to jump out of this sea vessel into the southeast winds and I will sit protecting our shadow

5 For more information about tandal and death in Lihir, see Gillespie and Bainton (2012). 
do ra wues melien $i$ tes

melien ma ngui lawir no ko kets

pilik tan a ton don wen ngui to

ri kowa tsunglik ra tandal tsatsul

manung laie sa wirwir se andal

kame lalong you and I jump into the sea

into the southeast winds and I will sit protecting our shadow oh you my brother the spirit has arrived within my ginger, he is swirling, there is blood in our mouths

(featured on Gillespie 2008: Track 6; www.lihir.info/music-of-lihir/index. $\mathrm{php} /$ the-songs/songs-nge)

Just one song was recorded in 2008 that also appeared in Schlaginhaufen's original collection. This was the bel song form sung on cylinder 50, according to Schlaginhaufen's documentation, by a woman called Simbi, who was 26 years old. The Lihir people I consulted about this song text said that it was not in everyday Lihir language. In fact, at present it remains untranslatable, as do a number of Schlaginhaufen's other recordings, because it employs a language no longer used or understood by most Lihirians. It is possible that this unknown language came to Lihir through now defunct trade routes with other parts of the region, but much work remains to ascertain its origins, if this is indeed possible. After playing this song to Alois Kokon, he declared he knew it, despite not being able to understand or translate its text, and to display his knowledge, he performed it for recording (see Gillespie 2008: Track 44; www.lihir.info/ music-of-lihir/index.php/the-songs/bual-apubutbut-bel) (Figure 11).

Because of the detail in Schlaginhaufen's notes, we were able to track the relatives of some of the 1908 singers, including the great-grandson of Simbi (Alois Balbal), pictured in Figure 12. This was aided by the fact that Lihir names are associated with particular areas and clans. 
13. PROTECTING OUR SHADOW

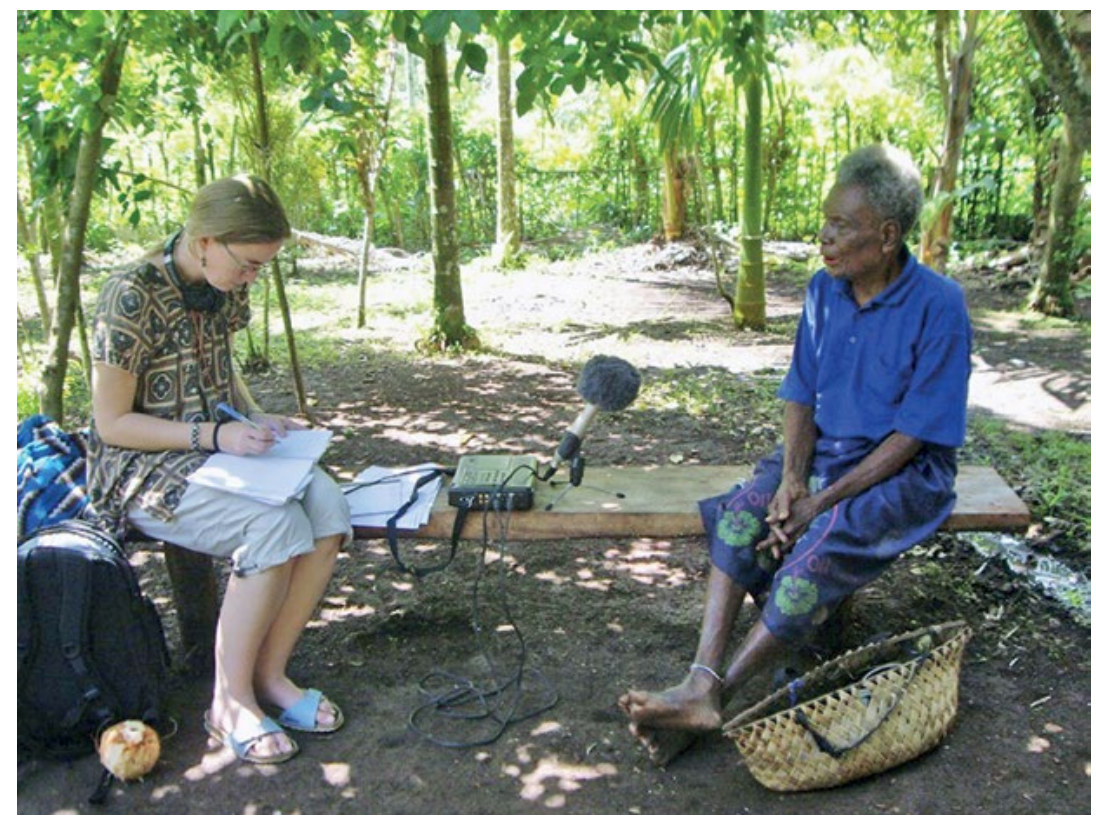

Figure 11. Kokon sings for recording while the author takes notes

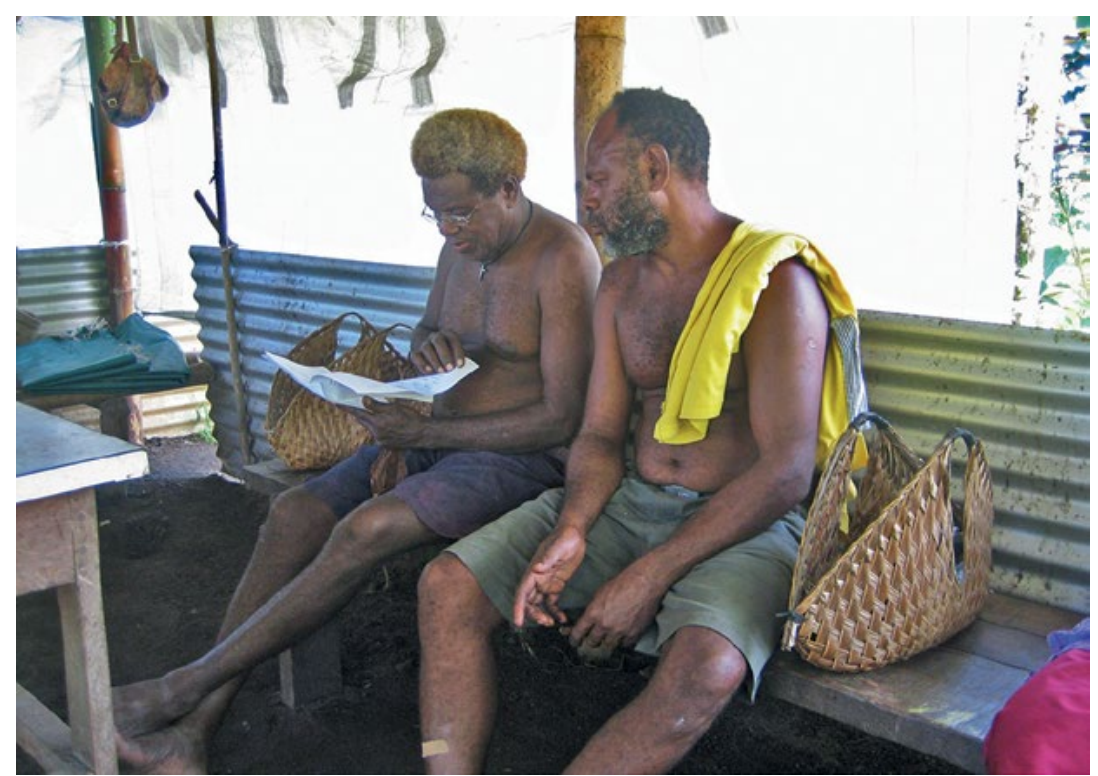

Figure 12. Simbi's great-grandson, Alois Balbal (left), with

Peter Toelinkanut, reading the Ziegler (2006) documentation on Schlaginhaufen's recordings 


\section{Protecting our shadow}

The repatriation of the 1908 recordings and the recording of Lihirian songs in the present day stimulated local interest and pride in Lihir traditions, especially amongst the younger generations who, due to study and employment, are more removed from the practice of such traditions in their daily lives. Lihir instruments, in particular a replica of a Lihir log drum or 'garamut' that was painted for the 2013 exhibition 'Musical Landscapes of Lihir' at the University of Queensland, have been promoted on Facebook pages (see Gillespie 2016: 21). In a direct nod to the Lihir CD Ae tinil wen Lir: Music of Lihir, its cover image (Figure 13) was also incorporated into a contemporary music clip celebrating Lihir culture some years ago (previously accessed on YouTube, the clip no longer appears to be available on that site).

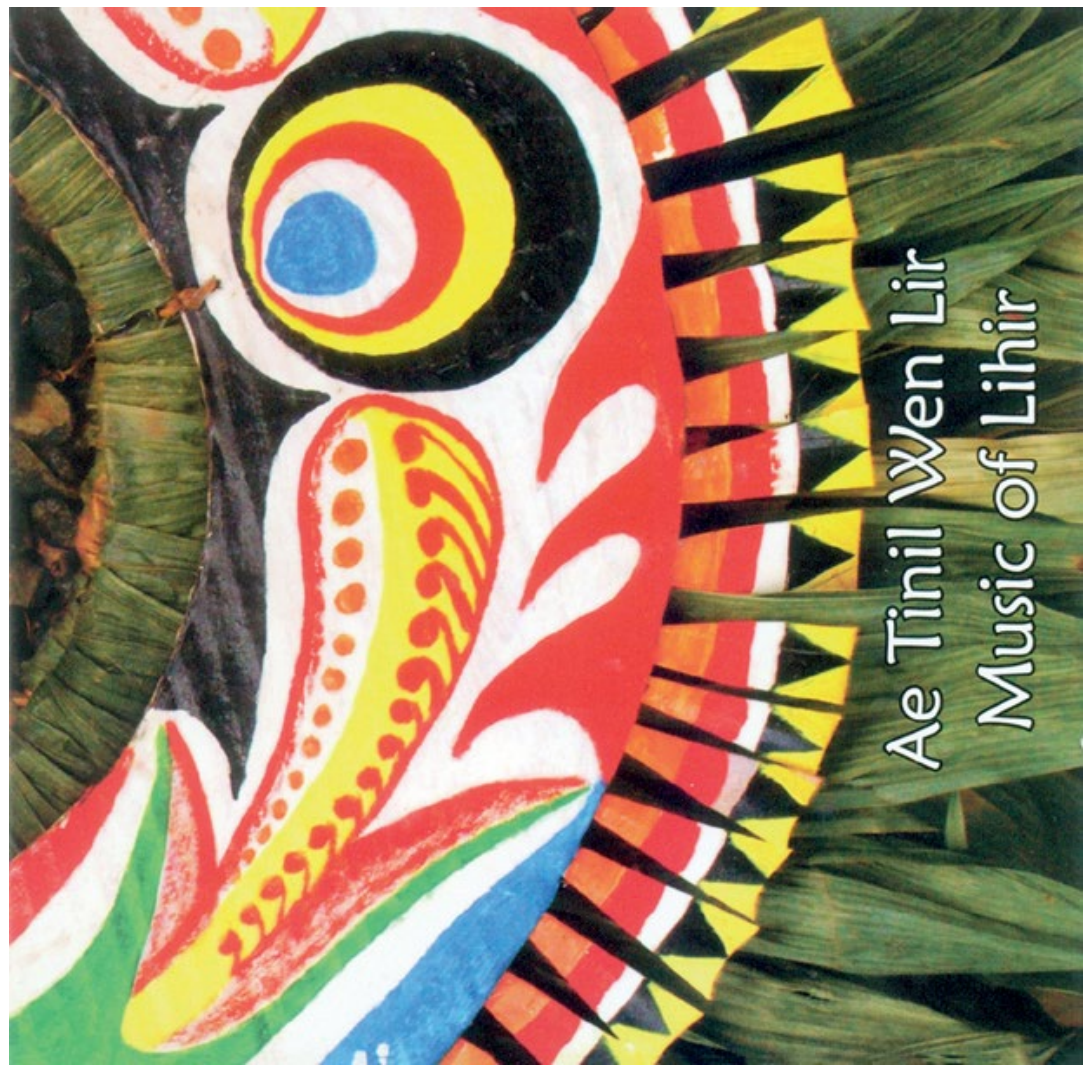

Figure 13. The cover of the CD Ae tinil wen Lir: Music of Lihir 
The CD Ae tinil wen Lir: Music of Libir was launched at Leo in 2009, at the same time as the Lihir Cultural Heritage Plan-a document brought together by the Lihir Cultural Heritage Committee that details what is felt to be important about Lihir culture and how it should be maintained into the future-was presented in draft form to the public (Lihir Cultural Heritage Committee 2009). ${ }^{6}$ This document, formally launched in 2011, clearly sets out the importance of engaging with archives and emphasises the role of the researcher in supporting Lihir people's engagement with them.

There are projects set out in the Lihir Cultural Heritage Plan that have not yet been realised. Some projects, such as the establishment of a cultural centre, may never eventuate at all. Funding for cultural heritage projects on Lihir since the time of this repatriation project has become increasingly restrained, due to the current mining company's fiscal situation and also due to local politics around the use of benefits from the company. To protect their legacy-their shadow-the researcher can continue to lobby the company and other possible sources of funding to find the means to realise these proposed projects and ideas. At the same time, however, the researcher should also be aware of the changing desires and priorities of the people. Lihir people continue to enact tradition vigorously through regular ritual performance and, in doing so, they continue to protect the shadow of their ancestors. Perhaps because of this, there is no urgency for projects such as a cultural centre to display this heritage out of context.

The future of archives is digital. Ethnomusicologists have on the whole embraced this technology, not only in accessing historical documents that have been made digital, as this case study illustrates, but also in recording, preserving, and archiving their own collections. One example is the archival facility PARADISEC (Pacific and Regional Archive for Digital Sources in Endangered Cultures) in which Australian ethnomusicologist Linda Barwick plays a leading role (www.paradisec.org.au). The internet is also being harnessed as a place to store and access digital collections. To this end, the activities and projects of the Lihir Cultural Heritage Committee, now the Lihir Cultural Heritage Association (or Lir Kalsarel Eritij Asosiesen in the Papua New Guinea language of Tok Pisin) are currently being uploaded into a new website (www.lihir.info). Already, the entire 2008 CD Ae tinil wen Lir: Music of Lihir can be accessed through

6 For a full account of the creation of this plan, see Bainton et al. (2011). 
this site (www.lihir.info/music-of-lihir) as I have indicated in the above examples. This is very useful, since only 1,000 copies of the CD were pressed at the time of publication, and enquiries for copies continue to be received. Now there is unlimited access to the recordings on the $C D$, so readers can experience first-hand the rich history and musical culture of the Lihir Islands.

\section{Acknowledgements}

This repatriation project was first presented in Across the World and Back Again: Repatriating Archival Recordings from Berlin to Lihir, Papua New Guinea', a paper presented at the 2008 annual conference of the Musicological Society of Australia at the University of Melbourne. I would like to thank Susanne Ziegler, formerly of the Berlin Phonogramm-Archiv, for originally providing me with the image of Schlaginhaufen's notes that appears as Figure 2, and the Berlin Phonogramm-Archiv for giving me the permission to use it here, as well as for their support for the CD to be made available freely online. In addition to honouring the legacy of Stephen Wild, to whom this festschrift is dedicated, this publication honours the memory of the singers of Lihir of times past, in particular Anap and more recently Agnes Toti (1929 10 May 2009) and Alois Kokon (c. 1925 - 21 January 2016), who sang the songs for recording that are reproduced here. It is also dedicated to the singers of Lihir of the present, who continue to respect and maintain the shadow of their ancestors.

\section{References cited}

Bainton, Nicholas A., Chris Ballard, Kirsty Gillespie. 2012. 'The End of the Beginning? Mining, Sacred Geographies, Memory and Performance in Lihir.' The Australian Journal of Anthropology 23 (1): 22-49. doi.org/10.1111/j.1757-6547.2012.00169.x.

Bainton, Nicholas A., Chris Ballard, Kirsty Gillespie, and Nicholas Hall. 2011. 'Stepping Stones across the Lihir Islands: Developing Cultural Heritage Management in the Context of a Gold-mining Operation.' International Journal of Cultural Property 18: 81-110. doi.org/10.1017/ S0940739111000087. 
Barz, Gregory F., and Timothy J. Cooley. 1997. eds. Shadows in the Field: New Perspectives for Fieldwork in Ethnomusicology. New York: Oxford University Press.

Berlin, Gabriele, and Artur Simon. 2002. eds. Music Archiving in the World: Papers Presented at the Conference on the Occasion of the 100th Anniversary of the Berlin Phonogramm-Archiv. Berlin: Verlag für Wissenschaft und Bildung.

Gillespie, Kirsty. 2008. Ae tinil wen Lir: Music of Libir. Compact disc. Lihir: Lihir Gold Ltd.

—_. 2013. 'Ethnomusicology and the Mining Industry: A Case Study from Lihir, Papua New Guinea.' Musicology Australia 35 (2): 178-90. doi.org/10.1080/08145857.2013.844486.

__. 2016. 'Musical Landscapes of Lihir: Exploring Performance and Place in a Museum Exhibition.' Perfect Beat 17 (1): 9-24. doi.org/ 10.1558/prbt.v17i1.27010.

Gillespie, Kirsty, and Nicholas A. Bainton. 2012. 'Coming Out of the Stone: Dangerous Heritage and the Death of the Twinhox Band.' Yearbook for Traditional Music 44: 71-86. doi.org/10.5921/ yeartradmusi.44.0071.

Hemer, Susan R. 2013. Tracing the Melanesian Person: Emotions and Relationships in Libir. Adelaide: University of Adelaide Press. doi.org/ 10.20851/lihir.

Lihir Cultural Heritage Committee. 2009. The Lihir Cultural Heritage Plan: Defining the Libir Cultural Heritage Program. Lihir: Lihir Cultural Heritage Committee.

Schlaginhaufen, Otto. 1959. Muliama: Zwei Jahre unter Südsee-Insulanern. Zürich: Orell Füssli Verlag.

Wild, Stephen. 2001. 'Forty Years of Facilitating: The Role of the Australian Institute of Aboriginal and Torres Strait Islander Studies in Research on Indigenous Music and Dance in Australia.' In Traditionalism and Modernity in the Music and Dance of Oceania, edited by Helen Reeves Lawrence and Don Niles, 151-75. Oceania Monograph, 52. Sydney: University of Sydney. 
A DISTINCTIVE VOICE IN THE ANTIPODES

Ziegler, Susanne. 2006. Die Wachszylinder des Berliner Phonogramm Archivs. Veröffentlichungen des Ethnographischen Museums Berlin, 73. Berlin: Ethnologisches Museum, Staatliche Museen zu Berlin. 
This text is taken from A Distinctive Voice in the Antipodes: Essays in Honour of Stephen A. Wild, edited by Kirsty Gillespie, Sally Treloyn and Don Niles, published 2017 by ANU Press, The Australian National University,

Canberra, Australia.

dx.doi.org/10.22459/DVA.07.2017.13 